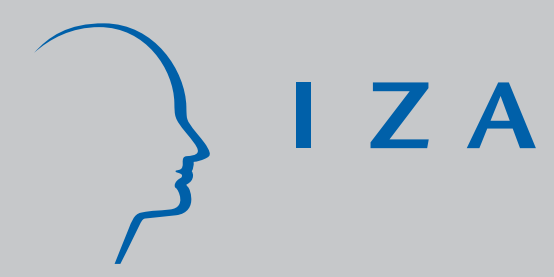

IZA DP No. 2139

Remittances, Institutions and Economic Growth

Natalia Catrinescu

Miguel Leon-Ledesma

Matloob Piracha

Bryce Quillin

May 2006 


\title{
Remittances, Institutions and Economic Growth
}

\author{
Natalia Catrinescu \\ European Commission
}

\author{
Miguel Leon-Ledesma \\ University of Kent \\ Matloob Piracha \\ University of Kent and IZA Bonn \\ Bryce Quillin \\ World Bank
}
Discussion Paper No. 2139
May 2006

\author{
IZA \\ P.O. Box 7240 \\ 53072 Bonn \\ Germany \\ Phone: +49-228-3894-0 \\ Fax: +49-228-3894-180 \\ Email: iza@iza.org
}

\begin{abstract}
Any opinions expressed here are those of the author(s) and not those of the institute. Research disseminated by IZA may include views on policy, but the institute itself takes no institutional policy positions.

The Institute for the Study of Labor (IZA) in Bonn is a local and virtual international research center and a place of communication between science, politics and business. IZA is an independent nonprofit company supported by Deutsche Post World Net. The center is associated with the University of Bonn and offers a stimulating research environment through its research networks, research support, and visitors and doctoral programs. IZA engages in (i) original and internationally competitive research in all fields of labor economics, (ii) development of policy concepts, and (iii) dissemination of research results and concepts to the interested public.
\end{abstract}

IZA Discussion Papers often represent preliminary work and are circulated to encourage discussion. Citation of such a paper should account for its provisional character. A revised version may be available directly from the author. 


\section{ABSTRACT}

\section{Remittances, Institutions and Economic Growth*}

There is considerable debate regarding the relative contribution of international migrants' remittances to sustainable economic development. While the rates and levels of officially recorded remittances to developing countries has increased enormously over the last decade, academic and policy-oriented research has not come to a consensus over whether remittances contribute to longer-term growth by building human and financial capital or degrade long-run growth by creating labor substitution and 'Dutch disease' effects. This paper suggests that contradictory findings have emerged when looking at the remittancesgrowth link because previous studies have not correctly controlled for endogeneity. Using Dynamic Data Panel estimates we find that remittances exert a weakly positive impact on long-term macroeconomic growth. The paper also considers the proposition that the longerterm developmental impact of remittances is increased in the presence of sound economic policies and institutions.

JEL Classification: F22, O15, O47

Keywords: international migration, remittances, growth, institutions

Corresponding author:

Matloob Piracha

Department of Economics

University of Kent

Canterbury, Kent CT2 7NP

United Kingdom

Email: M.E.Piracha@kent.ac.uk

\footnotetext{
* We would like thank seminar participants who commented on various parts of the research at the World Bank, OECD, IOM, ILO, and the Oxford University Centre on Migration, Policy, and Society. In particular, Ali Mansoor and Alessandra Venturini provided essential guidance on the overall design while Ralph Chami provided the data. The contents reflect the views of the authors and not necessarily those of the World Bank or the European Commission.
} 


\section{Remittances, Institutions and Economic Growth}

\section{INTRODUCTION}

Theoretical and empirical investigations into remittances' economic impact have produced highly mixed results. On the positive side, remittances contribute to the alleviation of poverty and, in some instances, provide capital to fund households' investments and savings. For a number of countries, international remittances have driven macroeconomic growth, mostly by increasing national disposable income. For many low income, net emigration countries, remittances are the most important source of external financing, leading FDI and official development assistance (Figure 1) ${ }^{2}$.

However, some studies have found that remittances can have a deleterious impact on national economic growth in the medium and longer term. ${ }^{3}$ Remittances can fuel inflation, disadvantage the tradable sector by appreciating the real exchange rate, and reduce labor market participation rates as receiving households opt to live off of migrants' transfers rather than by working. Moreover, remittances' contribution to growth and poverty might reduce the incentives for implementing sound macroeconomic policy or to institute any needed structural reforms.

In terms of the first strand of the debate, there is empirical evidence that remittances lead to positive economic growth, be it through their positive impact on consumption, savings or investment. Lucas (2005) cites several case studies that show signs that remittances may indeed have served to accelerate investment in Morocco, Pakistan, and India. Glytsos (2002) models the direct and indirect effects of remittances on incomes and hence on investment in seven Mediterranean countries, and finds that investment rises

\footnotetext{
${ }^{2}$ See World Bank (2006)

${ }^{3}$ Chami, Fullenkamp and Jajah (2003)
} 
with remittances in six out of the seven countries. Additionally, the results of the analysis conducted by Leon-Ledesma and Piracha (2004) for eleven transition economies of Eastern Europe during 1990-1999 show support for the view that remittances have a positive impact on productivity and employment both directly and indirectly through their effect on investment. Finally, a recent study by Roberts and Banaian (2004) on remittances in Armenia conclude that overall, empirical evidence suggests that the propensity to save out of remittance income is high (almost 40\%) and remarkably consistent across studies.

However, Giuliano and Ruiz-Arranz (2005) find that while remittances relationship with per capita GDP is not statistically significant, remittances do have a robust positive impact on financial development. Employing an empirical methodology that controls for the relationship between remittances and financial development and a new remittance dataset for middle and low income economies only, the authors find that remittances are correlated with indicators of financial development. Moreover, threshold analyses reveal that remittances appear to substitute for a well developed financial system by promoting growth more robustly in those countries with weak financial systems.

Figure 1: Leading Twenty Remittance Receiving Countries in the World as a Percentage of GDP (2004)

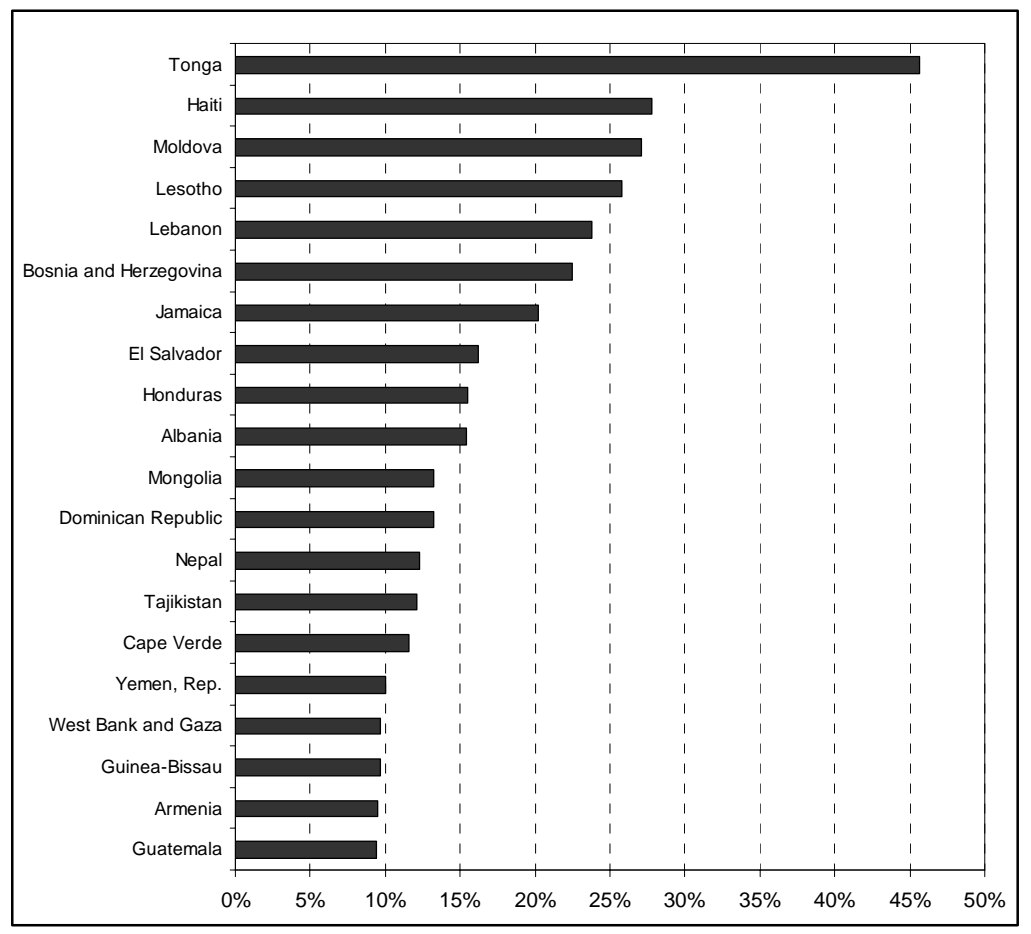


Source: IMF Balance of Payments Statistics Yearbook

Note: Remittances defined as the sum of received compensation of employees and workers' remittances

There are, nevertheless, at least two points of reservation regarding the effects of remittances. One is the possibility that countries can face a situation similar to the Dutch disease in which the inflow of remittances causes a real appreciation, or postpones depreciation, of the exchange rate. This has the effect of restricting export performance and hence possibly limiting output and employment. The second reservation relates to the argument put forward by Chami et al (2003) that income from remittances may be plagued by a moral hazard problem, permitting the migrant's family members to reduce their work effort. Their panel regressions support this view as they find remittances to be negatively correlated with growth among a sample of developing and developed economies from the early 1970s.

This paper seeks to fill two key gaps in the empirical study of remittances and growth. First the original specification utilized by Chami et al (2003) is modified with an estimator that controls for endogeneity. These authors explored endogeneity by estimating an IV regression that primarily employed the income gap and interest gap between the US and the remittance receiving country as an instrument. As Lucas (2005) indicates, the instrument used in the model does not seem to be effective in eliminating the bias, indicated particularly by the insignificance of the interest rate gap differential in the first stage.. This paper seeks to understand if the results that Chami et al obtain suffer from endogeneity that is not properly controlled for by estimating dynamic panel equations.

Second, we suggest that the key to increasing the longer-term development impact of remittances is to implement economic and governance policies that support a sound business investment environment, provide for the prudential security of the financial sector and quality public services (e.g. education and health care). Policies must favor savings and investment so that, at the margin, household income that exceeds the needs of basic subsistence can be saved or invested (including investment in human capital). The policies that are required for income convergence with industrialized countries more 
generally are also the ones that increase the development impact of remittances. As a result, we test the hypothesis that such policies condition the remittances to growth relationship.

There is some limited empirical work that suggests that institutions do influence the role that remittances play on long-term growth. Faini (2002) regressed income growth in source countries on a standard set of explanatory variables and on remittances. He found a positive impact of remittances on growth and interpreted the positive coefficient on the policy stance to indicate that in order for the full impact of remittances to be realized, which allow households to accumulate productive assets, a sound policy environment is needed - one that does not foster macroeconomic uncertainty, does not penalize agricultural activities, and supports the build-up of social and productive infrastructures. Moreover, in less systematic analysis, Ratha (2003) finds that during 1996-2000, remittance receipts averaged 0.5 percent of GDP in countries with a higher-than-median level of corruption compared to 1.9 percent in countries with lower-than-median corruption, giving an indication that corruption has an effect on the level of income generated from remittances.

The rest of the paper is organized as follows. Section II reports the data used in the paper while Section III presents the methodology used. Empirical results are discussed in Section IV and the last section concludes the paper.

\section{DATA}

\section{Data on Remittances}

The data on remittances was collected from the World Bank's World Development Indicators (WDI) database. ${ }^{4}$ The WDI data represents current transfers by migrant

\footnotetext{
${ }^{4}$ Note that the remittance data we use comprises workers' remittance and compensation of employees. This differs slightly from Chami et al as they only use workers' remittances in their analysis. However, it is
} 
workers and wages and salaries earned by nonresident workers. The data is reported by countries in their balance of payments (BoP).

There is a widespread consensus in the literature that the quality of data on remittances is extremely poor. It is well known that large quantities of international remittances are transmitted through “informal” channels such as "hawala” service providers, public transportation providers, or through friends and family and are not recorded in the balance of payments of many countries. ${ }^{5}$ Therefore, efforts to measure remittances suffer from important limitations as official estimates understate actual flows. In conducting any type of panel estimation with remittances data, one should also keep in mind the fact that better technology, decreased transfer transaction cost, and efforts to crack down on money laundering have generated a decrease in the unrecorded portion of remittance, which might create difficulties in determining whether a higher recorded amount represents remittance growth or improved reporting.

In addition, uneven reporting across countries and time results in panels that are significantly unbalanced - there are many missing values in the data set. In fact, if we look at the last 34 years (1970-2003), only twelve countries ${ }^{6}$ have reported observations for every year. Some 91 out of the 162 countries, for which at least one observation on remittances and compensation of employees is available, have 20 or more observations in this entire period. This situation, however, is to be expected since remittances have drawn significant attention for only the last several years. Moreover, in Eastern Europe and the former Soviet Union, international migration is a relatively new phenomenon. ${ }^{7}$

generally an accepted view that remittances as a whole should include both aspects of transfer (see Taylor, 1999).

${ }^{5}$ A recent World Bank survey of central banks in forty developing and emerging market economies found that only ten made efforts to collect data from informal channels when reporting international remittance levels in balance of payments statistics. See De Luna Martínez (2005).

${ }^{6}$ Algeria, Australia, Austria, Barbados, Colombia, Dominican Republic, India, Israel, Italy, Kenya,

Netherlands, and South Africa.

${ }^{7}$ See World Bank (forthcoming). 
Despite all the problems mentioned above, remittance flows tend to be the best measured aspect of the migration experience ${ }^{8}$. This dataset, which includes observation for 162 countries and spans a period of 34 years, is, to our knowledge, the best available consistent data on remittances.

\section{Data on Institutional Quality}

Unlike previous efforts to estimate the impact of international remittances on macroeconomic growth, we consider the role that the remittance receiving countries' policies and institutions play in conditioning this empirical relationship. We hypothesize that the policies that create the incentives for private sector investment and household savings generally will enhance the payoff from international remittances. That is, remittances receiving households will have an incentive to use migrants' transfers to start businesses, upgrade their human capital (through spending on health care and education, etc), and save funds in the formal financial system when the business regulatory environment is sound, public sector corruption is low, and the financial sector is prudentially secure. A country with such sound policies should, ceteris paribus, realize a higher payoff from international remittances.

To measure the role of such policies and institutions data on corruption indicators (Transparency International), and the UN human development indicator was employed. The TI Corruption Perceptions Index (CPI) ${ }^{9}$ ranks countries in terms of the degree to which corruption is perceived to exist among public officials and politicians. It is a composite index, drawing on corruption-related data in expert surveys and reflects the views of business people and analysts from around the world, including experts who are locals in the countries evaluated. Although the CPI index now covers 155 countries, it is available only starting 1995 and as few as 36 countries have continuous observations during 1995-2003.

\footnotetext{
${ }^{8}$ See Adams et al (2003).

${ }^{9}$ Transparency International, http://www.transparency.org/pressreleases_archive/2003/2003.10.07.cpi.en.html, retrieved April 3, 2005
} 
The human development index (UNHDI) ${ }^{10}$ focuses on three measurable dimensions of human development: living a long and healthy life, being educated and having a decent standard of living. Thus it combines measures of life expectancy, school enrolment, literacy and income to allow a broader view of a country's development than does income alone. The UNHDI covers 180 countries and some 100 of them have continuous observations for 28 years. However, it is not exactly a measure of quality of institutions and any coefficient on this variable should be treated with care.

Additionally, we collected governance research indicators developed by Kaufmann et al (2003), for six dimensions of governance:

- Voice and Accountability (measures the extent to which citizens of a country are able to participate in the selection of governments).

- Political Stability and Absence of Violence (captures the idea that the quality of governance in a country is compromised by the likelihood of wrenching changes in government).

- Government Effectiveness (focuses on “inputs” required for the government to be able to produce and implement good policies and deliver public goods).

- Regulatory Quality (measures the incidence of market-unfriendly policies such as price controls or inadequate bank supervision, as well as perceptions of the burdens imposed by excessive regulation in areas such as foreign trade and business development).

- Rule of Law (measures the success of a society in developing an environment in which fair and predictable rules form the basis for economic and social interactions, and importantly, the extent to which property rights are protected).

- Control of Corruption (measures perceptions of corruption conventionally defined as the exercise of public power for private gain).

The governance research indicators, albeit an appropriate measure of quality of institutions, are only available every other year between 1996 and 2002. In an effort to

\footnotetext{
${ }^{10}$ United Nations Human Development Reports, http://hdr.undp.org/statistics/, retrieved April 3, 2005
} 
find better data, we collected the political risk rating from the International Country Risk Guide (ICRG). This composite indicator assesses the political stability of a country and comprises 12 institutional measures - government stability, socioeconomic conditions, investment profile, internal conflict, external conflict, corruption, military in politics, religious tensions, law and order, ethnic tensions, democratic accountability, and bureaucracy quality. Data is available for 135 countries and spans over the period between 1984 and 2003. This is the longest and most comprehensive time-series measuring institutions in our dataset - as many as 102 countries have continuous observations over the entire 20-year period.

It is important to mention that there are crucial conceptual concerns connected with the manner in which institutional quality is measured. Rodrik (2004) points out, referring specifically to the indices we use in our paper, that the most commonly-used institutional quality measure are based on surveys of domestic and foreign investors, thus capturing perceptions rather than any of the formal aspects of the institutional setting. This in his view creates two important problems - perceptions are shaped not just by institutional environment, but also by many other aspects of the economic environment, creating endogeneity and reverse causality issues, and even when causality is established, the results do not indicate the specific institutional design that led to the measured outcome.

On the other hand, Moers (1999) notes that use of subjective institutional measures instead of objective institutional measures in growth empirics is quite consistently verified and considers it a promising research avenue. Despite the obvious shortcomings, this paper will employ the indices described above merely to find an indication that the institutional environment might have an impact on the relationship between remittances and economic growth, leaving it for further research to consider in more detail on how significant this impact is and how exactly does the relationship play out. 


\section{Methodology}

As mentioned above, we extend the model developed by Chami et al, which posits that since remittance transfer takes place under asymmetric information and uncertainty, remittances are burdened with a moral hazard problem that limits their ability to contribute to positive business and human capital investment in developing economies, thus leading to negative economic growth. After briefly outlining their model, we show how, using the same general empirical methodology but making slight modifications and adding institution variables, the results could be significantly different from those obtained by Chami et al.

Using panel data on worker's remittances, per capita GDP, gross capital formation (formerly categorized as gross domestic investment), and net private capital flows (all reported over the period 1970-1998), Chami et al first examine the relationship between worker remittances and per capita GDP growth using standard population-averaged cross-section estimation. The estimated equation is based on:

$$
\Delta y_{i}=\beta_{0}+\beta_{1} y_{0 i}+\beta_{2} w r_{i}+\beta_{3} g c f_{i}+\beta_{4} n p c f_{i}+u_{i}
$$

where $y$ is the log of real GDP per capita, $y_{0}$ is the initial value of $y$, wr is the log of worker remittances to GDP ratio, $g c f$ is the log of gross capital formation to GDP ratio, and $n p c f$ is the log of net private capital flows to GDP ratio. They also use an alternative specification using change in the log workers remittances to GDP ratio as an independent variable:

$$
\Delta y_{i}=\beta_{0}+\beta_{1} y_{0 i}+\beta_{2} \Delta w r_{i}+\beta_{3} g c f_{i}+\beta_{4} n p c f_{i}+u_{i}
$$

This specification is problematic in the following way: a country would need to increase remittances year after year to promote growth, which would end up with us having a 100 percent share of remittances on GDP in the limit. Therefore, unlike Chami et al, we look at the level, rather than growth, of remittances to GDP. 
Furthermore, as mentioned above, we include institutional quality variables that, a priori, seem important. Also, abstracting for missing observations, our dataset adds 5 years of observations to the data considered by the Chami model and covers the period 19702003.

Lastly, and more importantly, Chami et al do not address the problems associated with running panel estimations. One possible problem arising from the panel specifications is that estimated coefficients may be biased if errors are autocorrelated due to mispecified dynamics. It is very likely that growth is autocorrelated due to business cycle effects. One solution would be to pool observations from peak to peak of the business cycle or take 5 or 6 years averages of the data. The first option is implausible as it would require a priori knowledge of business cycle features for each economy. The second appears to be very arbitrary. Both options also lead to a large loss of information.

Another, more rigorous, alternative is to model these dynamics by introducing the lagged rate of growth of per capita income as an independent variable. This however, leads to some estimation problems that have to be dealt with by using Dynamic Panel Data (DPD) estimators. In our estimations we used the annual data and introduced one lag of the rate of growth of per capita GDP. The estimator used in most equations is the Anderson and Hsiao (1981) method. This method estimates the equation in first differences and instrumentalizes the lagged growth of GDPpc by using its lagged level in $t-2$. This estimation method is superior to the popular Arellano and Bond (1991) GMM estimator for the typical macroeconomic panel datasets as demonstrated by Judson and Owen (1999). Nevertheless, the results of using the GMM estimator are also relevant as we do not have specific Monte Carlo evidence on the appropriateness of each estimator for our panel settings. In both cases we provide a 2-step estimator.

Another potential problem that arises is the endogeneity of the remittances variables. This can arise because it is likely that countries experiencing less successful economic performance would receive larger remittances from their émigrés. To deal with this 
problem, we have estimated the equations instrumentalizing also the remittances variable with its first and second lagged level in the transformed (first difference) equation. This is different from Chami et al, as we believe their results are heavily biased in the absence of this IV estimator.

In all the estimations we have used the logarithm of the Remittances/GDP ratio as independent variable, as well as the control variables mentioned in the previous estimates. We provide the estimated coefficients and their standard errors, the p-value of a Wald test of joint model significance (high p-values indicate joint significance), the pvalue of the Sargan test for instrument validity (high p-values indicate valid instruments) and p-values of autocorrelation tests of order 1 and 2. Note that autocorrelation of order 1 is expected due to first differencing even if the original level errors are not autocorrelated unless they follow a random walk. Finally we provide the long-run dynamic solution for the coefficient on remittances and its standard error, which is to be interpreted as the impact of remittances on growth in equilibrium. We use several specifications depending on the control variables introduced in the regression. We provide, in specifications (1) to (6), the results from the Andreson-Hsiao estimator. Specifications (7) to (9) present the results from estimating the model using a 2-steps GMM estimator with robust standard errors.

\section{EMPIRICAL ESTIMATES}

The results of the analysis are indicated in the attached Tables 1 through 5 . The main result of our analysis is that, albeit no firm conclusions can be made regarding the effect of remittances on economic growth, models that account for endogeneity concerns indicate that remittances make a positive, albeit modest, contribution to growth. 
The cross-section and panel analysis ${ }^{11}$ conducted in accordance with the Chami et al model, over two separate periods, 1970-2003 and 1991-2003, show inconclusive results, but certainly do not find a negative relationship between remittances and economic growth (Tables 1 through 4). The robustness of the coefficients on remittances depends on model specifications, but in the instances where results are significant, they show a positive effect of remittances on growth. The inclusion of institutional variables also yields inconclusive results, which could be due to the severe endogeneity problems associated with both remittance estimations and the use of subjective institutional indices. The cross section analysis conducted as the average over the same two periods leads to a similar outcome. However, albeit the panel and cross section estimations (Table 1 and 2) produce uncertain results, they do not give any indication that remittances have a negative impact in nature as suggested by Chami et al.

Moreover, certain panel and cross-section estimations conducted with data on workers' remittances only, as in Chami et al., showed a highly robust positive correlation between increase in remittances and GDP growth if institutional quality is accounted for. The consensus in the empirical literature, however, is that data on workers' remittances alone does not reflect fully the amount of money remitted by migrants, and thus the results of these estimation are not reported here. ${ }^{12}$

The results of the dynamic panel estimations are shown in Table 5. We present first the estimate of a simple dynamic model with remittances as the only independent variable and then add different control variables at a time. Specification (9) only includes variables that appeared to be significant in at least one of the previous equations. The inclusion of the TICI index and the UNHDI reduce dramatically the number of observations and countries, although this is also the case for the rest of institutional variables. The result is a shorter panel, especially in the time dimension, in which we end up with 4-5 consecutive time series per country (this is an unbalanced panel). In that context the GMM estimator is more reliable than the AH estimator. The Wald test for the

\footnotetext{
${ }^{11}$ The choice of fixed-effects or random-effects models in each instance was determined by the results of the Hausman test.

${ }^{12}$ These are available on request from the corresponding author.
} 
$\mathrm{AH}$ estimator when these variables are included show clearly that the model is not significant and is grossly mispecified. For this reason, we recommend looking at the results provided in equations (1) to (3) and (7) to (9).

The main result is that remittances appear to have a positive and statistically significant impact on growth in five out of nine of these specifications. Only in one specification the impact is negative but not significant (when we do not instrumentalize or use control variables). The significant long-run coefficients range from 0.001 to 0.022 . This denotes that the estimates cannot be considered to be very robust. What seems to be more robust, however, is the fact that, if anything, remittances appear to have a positive effect on growth. The other important result is that the impact of remittances appears to be more positive when (i) we control for the potential endogeneity bias in remittances and (ii) we consider remittances in conjunction with institutional variables that, in general, also appear to be significant and show the expected sign.

\section{CONCLUSION}

Our Dynamic Panel Data analysis, which accounts correctly for the mispecified dynamics and endogeneity problems that plagued previous research, yields positive and significant estimators of remittances in most of the considered specifications. We could, therefore, safely conclude that we can reject the existence of a negative impact of remittances on growth and that there is some indication of a positive, albeit mild, impact.

Moreover, both the conceptual and empirical analyses seem to point to the fact that institutions can play a role in how remittances affect economic growth. A sound institutional environment has been found to affect the volume and efficiency of investment; hence in the presence of good institutions, remittances could be invested in a greater amount and more efficiently, ultimately leading to higher output. At the very least, this conclusion warrants further research in this area. 
If further evidence supports the proposition laid out above, this could also have significant policy implications. A number of researchers have expressed skepticism regarding the ability of governments to affect the manner in which remittances are used. For example, Kapur (2004) points out that active government attempts to encourage or require remittances to be invested are unlikely to have significant economic benefit. If, however, it is found that institutions matter for the manner in which remittances are used, then the best way for recipient country governments to ensure that remittances contribute to positive economic growth is to foster better quality of institutions, thus ensuring that a greater proportion of remittances is utilized for productive investment.

Based on the analysis and conclusions above, recommendations could be divided into suggestions for further research and available policy options:

Further research should test whether the proposition is robust to the use of other types of growth regressions and models. Noting the difficult of endogeneity relationship between remittances, institutions, and growth on one hand, and remittances, institutions and investment on the other hand, it might be helpful to focus on how institutions influence the effect of remittances on investment first, and then determine what the general implications for economic growth are.

However, even if a separate equation for investment is introduced, the direct and indirect effects of remittances and institutions on growth will most likely be difficult to disentangle and as such will have little value in devising policy recommendations. Therefore qualitative case studies might be more helpful for determining the exact manner in which institutions influence remittance use and what policies might help governments ensure that remittances foster economic growth. 
Table 1: Remittances (in percent of GDP) and Economic Growth: Cross Section Estimation OLS (1970-2003)

\begin{tabular}{|c|c|c|c|c|c|}
\hline $\begin{array}{l}\text { Dependent Variable: } \\
\text { Log(GDP Per Capita } \\
\text { Growth) }\end{array}$ & (1) & (2) & (3) & (4) & $\begin{array}{l}\text { (5) } \\
\text { Quadratic }\end{array}$ \\
\hline Log(GDP Per Capita 1970) & $\begin{array}{l}-0.003 * \\
(0.002)\end{array}$ & $\begin{array}{l}-0.014 * * * \\
(0.002)\end{array}$ & $\begin{array}{l}-0.006^{* * *} \\
(0.001)\end{array}$ & $\begin{array}{l}-0.007 * * * \\
(0.002)\end{array}$ & $\begin{array}{l}-0.007 * * * \\
(0.002)\end{array}$ \\
\hline $\begin{array}{l}\text { Log(Remittances/GDP) } \\
(\text { Log(Remittances/GDP }))^{2}\end{array}$ & $\begin{array}{l}0.001 \\
(0.001)\end{array}$ & $\begin{array}{l}-0.000 \\
(0.001)\end{array}$ & $\begin{array}{l}0.000 \\
(0.001)\end{array}$ & $\begin{array}{l}0.001 \\
(0.001)\end{array}$ & $\begin{array}{l}0.001 \\
(0.001) \\
0.000 \\
(0.001)\end{array}$ \\
\hline $\log (\mathrm{GCF} / \mathrm{GDP})$ & $\begin{array}{l}0.041 * * * \\
(0.008)\end{array}$ & $\begin{array}{l}0.028 * * * \\
(0.006)\end{array}$ & $\begin{array}{l}0.037 * * * \\
(0.005)\end{array}$ & $\begin{array}{l}0.039 * * * \\
(0.007)\end{array}$ & $\begin{array}{l}0.039 * * * \\
(0.007)\end{array}$ \\
\hline Log(NPCF/GDP) & $\begin{array}{l}0.000 \\
(0.002)\end{array}$ & $\begin{array}{l}-0.003 * * \\
(0.002)\end{array}$ & $\begin{array}{l}-0.002 \\
(0.001)\end{array}$ & $\begin{array}{l}-0.004 \\
(0.002)\end{array}$ & $\begin{array}{l}-0.003 \\
(0.002)\end{array}$ \\
\hline TI Corruption Index & & $\begin{array}{l}0.004 * * * \\
(0.001)\end{array}$ & & & \\
\hline UNHDI & & $\begin{array}{l}0.083 * * * \\
(0.017)\end{array}$ & & & \\
\hline Voice and Accountability & & & $\begin{array}{l}-0.004 \\
(0.003)\end{array}$ & & \\
\hline Political Stability & & & $\begin{array}{l}-0.001 \\
(0.003)\end{array}$ & & \\
\hline Government Efficiency & & & $\begin{array}{l}0.005 \\
(0.005)\end{array}$ & & \\
\hline Regulatory Quality & & & $\begin{array}{l}0.004 \\
(0.004)\end{array}$ & & \\
\hline Rule of Law & & & $\begin{array}{l}0.016^{* *} \\
(0.006)\end{array}$ & & \\
\hline Corruption & & & $\begin{array}{l}-0.004 \\
(0.006)\end{array}$ & & \\
\hline $\begin{array}{l}\text { ICRG Composite Political } \\
\text { Risk Indicator }\end{array}$ & & & & $0.001 * * *$ & $0.001^{* * *}$ \\
\hline Constant & $\begin{array}{l}-0.090^{* * *} \\
(0.021)\end{array}$ & $\begin{array}{l}-0.044^{* *} \\
(0.022)\end{array}$ & $\begin{array}{l}-0.052 * * * \\
(0.016)\end{array}$ & $\begin{array}{l}(0.000) \\
-0.111^{* * *} \\
(0.023)\end{array}$ & $\begin{array}{l}(0.000) \\
-0.110^{* * *} \\
(0.023)\end{array}$ \\
\hline Observations & 77 & 69 & 75 & 62 & 62 \\
\hline R-squared & 0.44 & 0.71 & 0.72 & 0.55 & 0.55 \\
\hline
\end{tabular}


Table 2: Remittances (in percent of GDP) and Economic Growth: Cross Section Estimation OLS (1991-2003)

\begin{tabular}{|c|c|c|c|c|c|}
\hline $\begin{array}{l}\text { Dependent Variable: } \\
\text { Log(GDP Per Capita } \\
\text { Growth) }\end{array}$ & (1) & (2) & (3) & (4) & $\begin{array}{l}\text { (5) } \\
\text { Quadratic }\end{array}$ \\
\hline Log(GDP Per Capita 1970) & $\begin{array}{l}-0.001 \\
(0.002)\end{array}$ & $\begin{array}{l}-0.004 \\
(0.005)\end{array}$ & $\begin{array}{l}-0.007 * * * \\
(0.002)\end{array}$ & $\begin{array}{l}-0.004 \\
(0.003)\end{array}$ & $\begin{array}{l}-0.004 \\
(0.003)\end{array}$ \\
\hline $\begin{array}{l}\text { Log(Remittances/GDP) } \\
(\text { Log(Remittances/GDP }))^{2}\end{array}$ & $\begin{array}{l}0.000 \\
(0.001)\end{array}$ & $\begin{array}{l}-0.000 \\
(0.002)\end{array}$ & $\begin{array}{l}-0.000 \\
(0.001)\end{array}$ & $\begin{array}{l}0.001 \\
(0.002)\end{array}$ & $\begin{array}{l}0.001 \\
(0.002) \\
-0.000 \\
(0.001)\end{array}$ \\
\hline $\log (\mathrm{GCF} / \mathrm{GDP})$ & $\begin{array}{l}0.027 * * * \\
(0.009)\end{array}$ & $\begin{array}{l}0.024^{* *} \\
(0.010)\end{array}$ & $\begin{array}{l}0.027 * * * \\
(0.008)\end{array}$ & $\begin{array}{l}0.022^{*} \\
(0.011)\end{array}$ & $\begin{array}{l}0.022^{*} \\
(0.011)\end{array}$ \\
\hline Log(NPCF/GDP) & $\begin{array}{l}0.000 \\
(0.002)\end{array}$ & $\begin{array}{l}0.001 \\
(0.003)\end{array}$ & $\begin{array}{l}0.000 \\
(0.002)\end{array}$ & $\begin{array}{l}0.001 \\
(0.003)\end{array}$ & $\begin{array}{l}0.001 \\
(0.003)\end{array}$ \\
\hline TI Corruption Index & & $\begin{array}{l}0.006 * * * \\
(0.002)\end{array}$ & & & \\
\hline UNHDI & & $\begin{array}{l}0.003 \\
(0.031)\end{array}$ & & & \\
\hline Voice and Accountability & & & $\begin{array}{l}-0.009 * * \\
(0.004)\end{array}$ & & \\
\hline Political Stability & & & $\begin{array}{l}0.002 \\
(0.004)\end{array}$ & & \\
\hline Government Efficiency & & & $\begin{array}{l}0.014 \\
(0.009)\end{array}$ & & \\
\hline Regulatory Quality & & & $\begin{array}{l}0.012 * * \\
(0.006)\end{array}$ & & \\
\hline Rule of Law & & & $\begin{array}{l}-0.001 \\
(0.009)\end{array}$ & & \\
\hline Corruption & & & $\begin{array}{l}0.005 \\
(0.008)\end{array}$ & & \\
\hline $\begin{array}{l}\text { ICRG Composite Political } \\
\text { Risk Indicator }\end{array}$ & & & & 0.001 & 0.001 \\
\hline Constant & $\begin{array}{l}-0.069 * * * \\
(0.026)\end{array}$ & $\begin{array}{l}-0.059 * \\
(0.030)\end{array}$ & $\begin{array}{l}-0.021 \\
(0.022)\end{array}$ & $\begin{array}{l}(0.000) \\
-0.066^{* *} \\
(0.030)\end{array}$ & $\begin{array}{l}(0.000) \\
-0.065^{* *} \\
(0.031)\end{array}$ \\
\hline $\begin{array}{l}\text { Observations } \\
\text { R-squared }\end{array}$ & $\begin{array}{l}119 \\
0.13\end{array}$ & $\begin{array}{l}104 \\
0.20\end{array}$ & $\begin{array}{l}114 \\
0.40\end{array}$ & $\begin{array}{l}90 \\
0.17\end{array}$ & $\begin{array}{l}90 \\
0.17\end{array}$ \\
\hline
\end{tabular}

Robust standard errors in parentheses

* significant at $10 \%$; ** significant at $5 \%$; *** significant at $1 \%$ 
Table 3: Remittances (in percent of GDP) and Economic Growth: Panel Estimation (1970-2003)

\begin{tabular}{|c|c|c|c|c|c|c|}
\hline $\begin{array}{l}\text { Dependent Variable: } \\
\text { Log(GDP Per Capita } \\
\text { Growth) }\end{array}$ & (1) & (2) & (3) & (4) & $\begin{array}{l}\text { (5) } \\
\text { Quadratic }\end{array}$ & $\begin{array}{l}\text { (6) } \\
\text { Quadratic }\end{array}$ \\
\hline Growth GDPpc (t-1) & $\begin{array}{l}0.180 * * * \\
(0.020)\end{array}$ & $\begin{array}{l}0.299 * * * \\
(0.057)\end{array}$ & $\begin{array}{l}-0.068 * \\
(0.038)\end{array}$ & $\begin{array}{l}0.017 \\
(0.028)\end{array}$ & $\begin{array}{l}0.097 * * * \\
(0.020)\end{array}$ & $\begin{array}{l}0.018 \\
(0.028)\end{array}$ \\
\hline $\begin{array}{l}\text { Log(Remittances/GDP) } \\
(\text { Log(Remittances/GDP }))^{2}\end{array}$ & $\begin{array}{l}0.001 * * \\
(0.001)\end{array}$ & $\begin{array}{l}-0.000 \\
(0.001)\end{array}$ & $\begin{array}{l}0.003 \\
(0.003)\end{array}$ & $\begin{array}{l}0.000 \\
(0.002)\end{array}$ & $\begin{array}{l}0.006 * * * \\
(0.001) \\
0.001^{*} \\
(0.000)\end{array}$ & $\begin{array}{l}0.003 \\
(0.002) \\
0.001 * * \\
(0.001)\end{array}$ \\
\hline Log(GCF/GDP) & $\begin{array}{l}0.030 * * * \\
(0.003)\end{array}$ & $\begin{array}{l}0.029 * * * \\
(0.007)\end{array}$ & $\begin{array}{l}0.065 * * * \\
(0.009)\end{array}$ & $\begin{array}{l}0.045 * * * \\
(0.006)\end{array}$ & $\begin{array}{l}0.036 * * * \\
(0.004)\end{array}$ & $\begin{array}{l}0.045 * * * \\
(0.006)\end{array}$ \\
\hline Log(NPCF/GDP) & $\begin{array}{l}0.001 \\
(0.001)\end{array}$ & $\begin{array}{l}0.004 * \\
(0.002)\end{array}$ & $\begin{array}{l}-0.001 \\
(0.002)\end{array}$ & $\begin{array}{l}-0.000 \\
(0.001)\end{array}$ & $\begin{array}{l}0.001 \\
(0.001)\end{array}$ & $\begin{array}{l}-0.000 \\
(0.001)\end{array}$ \\
\hline TI Corruption Index & & $\begin{array}{l}0.001 \\
(0.002)\end{array}$ & & & & \\
\hline UNHDI & & $\begin{array}{l}-0.018 \\
(0.018)\end{array}$ & & & & \\
\hline Voice and Accountability & & & $\begin{array}{l}0.005 \\
(0.009)\end{array}$ & & & \\
\hline Political Stability & & & $\begin{array}{l}0.005 \\
(0.005)\end{array}$ & & & \\
\hline Government Efficiency & & & $\begin{array}{l}-0.011 \\
(0.007)\end{array}$ & & & \\
\hline Regulatory Quality & & & $\begin{array}{l}0.003 \\
(0.006)\end{array}$ & & & \\
\hline Rule of Law & & & $\begin{array}{l}-0.017 \\
(0.011)\end{array}$ & & & \\
\hline Corruption & & & $\begin{array}{l}-0.006 \\
(0.008)\end{array}$ & & & \\
\hline $\begin{array}{l}\text { ICRG Composite Political } \\
\text { Risk Indicator }\end{array}$ & & & & -0.000 & & -0.000 \\
\hline Constant & $\begin{array}{l}-0.080^{* * *} \\
(0.010)\end{array}$ & $\begin{array}{l}-0.074 * * * \\
(0.023)\end{array}$ & $\begin{array}{l}-0.184 * * * \\
(0.026)\end{array}$ & $\begin{array}{l}(0.000) \\
-0.117^{* * *} \\
(0.019)\end{array}$ & $\begin{array}{l}-0.097^{* * *} \\
(0.014)\end{array}$ & $\begin{array}{l}(0.000) \\
-0.120^{* * *} \\
(0.019)\end{array}$ \\
\hline Observations & 1913 & 297 & 716 & 1108 & 1913 & 1108 \\
\hline Number of ID & 123 & 80 & 114 & 91 & 123 & 91 \\
\hline R-squared & & & 0.11 & 0.06 & 0.08 & 0.07 \\
\hline
\end{tabular}

Standard errors in parentheses

* significant at $10 \%$; ** significant at $5 \%$; *** significant at $1 \%$ 
Table 4: Remittances (in percent of GDP) and Economic Growth: Panel Estimation (1991-2003)

\begin{tabular}{|c|c|c|c|c|c|c|}
\hline $\begin{array}{l}\text { Dependent Variable: } \\
\text { Log(GDP Per Capita } \\
\text { Growth) }\end{array}$ & (1) & (2) & (3) & (4) & $\begin{array}{l}\text { (5) } \\
\text { Quadratic }\end{array}$ & $\begin{array}{l}\text { (6) } \\
\text { Quadratic }\end{array}$ \\
\hline Growth GDPpc (t-1) & $\begin{array}{l}0.143 * * * \\
(0.026)\end{array}$ & $\begin{array}{l}0.299 * * * \\
(0.057)\end{array}$ & $\begin{array}{l}-0.068 * \\
(0.038)\end{array}$ & $\begin{array}{l}-0.027 \\
(0.034)\end{array}$ & $\begin{array}{l}0.078 * * * \\
(0.027)\end{array}$ & $\begin{array}{l}-0.027 \\
(0.034)\end{array}$ \\
\hline $\begin{array}{l}\text { Log(Remittances/GDP) } \\
(\log (\text { Remittances/GDP }))^{2}\end{array}$ & $\begin{array}{l}0.001 \\
(0.001)\end{array}$ & $\begin{array}{l}-0.000 \\
(0.001)\end{array}$ & $\begin{array}{l}0.003 \\
(0.003)\end{array}$ & $\begin{array}{l}-0.004 \\
(0.002)\end{array}$ & $\begin{array}{l}0.001 \\
(0.002) \\
-0.001 \\
(0.001)\end{array}$ & $\begin{array}{l}-0.003 \\
(0.003) \\
0.000 \\
(0.001)\end{array}$ \\
\hline $\log (\mathrm{GCF} / \mathrm{GDP})$ & $\begin{array}{l}0.038 * * * \\
(0.005)\end{array}$ & $\begin{array}{l}0.029 * * * \\
(0.007)\end{array}$ & $\begin{array}{l}0.065 * * * \\
(0.009)\end{array}$ & $\begin{array}{l}0.061 * * * \\
(0.008)\end{array}$ & $\begin{array}{l}0.056 * * * \\
(0.007)\end{array}$ & $\begin{array}{l}0.061 * * * \\
(0.008)\end{array}$ \\
\hline Log(NPCF/GDP) & $\begin{array}{l}0.002 \\
(0.001)\end{array}$ & $\begin{array}{l}0.004 * \\
(0.002)\end{array}$ & $\begin{array}{l}-0.001 \\
(0.002)\end{array}$ & $\begin{array}{l}-0.000 \\
(0.002)\end{array}$ & $\begin{array}{l}0.001 \\
(0.001)\end{array}$ & $\begin{array}{l}-0.000 \\
(0.002)\end{array}$ \\
\hline TI Corruption Index & & $\begin{array}{l}0.001 \\
(0.002)\end{array}$ & & & & \\
\hline UNHDI & & $\begin{array}{l}-0.018 \\
(0.018)\end{array}$ & & & & \\
\hline Voice and Accountability & & & $\begin{array}{l}0.005 \\
(0.009)\end{array}$ & & & \\
\hline Political Stability & & & $\begin{array}{l}0.005 \\
(0.005)\end{array}$ & & & \\
\hline Government Efficiency & & & $\begin{array}{l}-0.011 \\
(0.007)\end{array}$ & & & \\
\hline Regulatory Quality & & & $\begin{array}{l}0.003 \\
(0.006)\end{array}$ & & & \\
\hline Rule of Law & & & $\begin{array}{l}-0.017 \\
(0.011)\end{array}$ & & & \\
\hline Corruption & & & $\begin{array}{l}-0.006 \\
(0.008)\end{array}$ & & & \\
\hline $\begin{array}{l}\text { ICRG Composite Political } \\
\text { Risk Indicator }\end{array}$ & & & & 0.000 & & 0.000 \\
\hline Constant & $\begin{array}{l}-0.102^{* * *} \\
(0.016)\end{array}$ & $\begin{array}{l}-0.074^{* * *} \\
(0.023)\end{array}$ & $\begin{array}{l}-0.184 * * * \\
(0.026)\end{array}$ & $\begin{array}{l}(0.000) \\
-0.194^{* * *} \\
(0.028)\end{array}$ & $\begin{array}{l}-0.155^{* * *} \\
(0.021)\end{array}$ & $\begin{array}{l}(0.000) \\
-0.194 * * * \\
(0.028)\end{array}$ \\
\hline Observations & 1079 & 297 & 716 & 807 & 1079 & 807 \\
\hline Number of ID & 122 & 80 & 114 & 91 & 122 & 91 \\
\hline R-squared & & & 0.11 & 0.10 & 0.10 & 0.10 \\
\hline
\end{tabular}

Standard errors in parentheses

* significant at $10 \%$; ** significant at $5 \%$; *** significant at $1 \%$ 
Table 5: Worker Remittances and Growth:

Dynamic Panel Estimation (1970-2003)

\begin{tabular}{|c|c|c|c|c|c|c|}
\hline $\begin{array}{l}\text { Dependant Variable: growth of } \\
\text { GDP Per Capita } \\
\text { Endogenous Variable: Log } \\
\text { (Remittances/GDP) }\end{array}$ & $\begin{array}{l}\text { (1) } \\
\mathrm{AH}\end{array}$ & $\begin{array}{c}(2) \\
\text { AH-IV }\end{array}$ & $\begin{array}{c}\text { (3) } \\
\text { AH-IV }\end{array}$ & $\begin{array}{c}(4) \\
\text { AH-IV }\end{array}$ & $\begin{array}{c}\text { (5) } \\
\text { AH-IV }\end{array}$ & $\begin{array}{c}(6) \\
\text { AH-IV }\end{array}$ \\
\hline Growth GDPpc (t-1) & $\begin{array}{c}0.202^{\wedge} \\
(0.014)\end{array}$ & $\begin{array}{c}0.170^{\wedge} \\
(0.006)\end{array}$ & $\begin{array}{c}0.132^{\wedge} \\
(0.005)\end{array}$ & $\begin{array}{c}0.083 \wedge \\
(0.000)\end{array}$ & $\begin{array}{c}0.035 \\
(0.071)\end{array}$ & $\begin{array}{c}0.037 \wedge \\
(0.013)\end{array}$ \\
\hline Log(Remittances/GDP Growth) & $\begin{array}{c}-0.005 \\
(0.010)\end{array}$ & $\begin{array}{l}0.002^{*} \\
(0.001)\end{array}$ & $\begin{array}{c}0.002 \\
(0.001)\end{array}$ & $\begin{array}{c}0.001 * * \\
(0.000)\end{array}$ & $\begin{array}{c}0.021 * * \\
(0.090)\end{array}$ & $\begin{array}{l}0.012^{\wedge} \\
(0.002)\end{array}$ \\
\hline $\log (\mathrm{GCF} / \mathrm{GDP})$ & & & $\begin{array}{l}0.082^{\wedge} \\
(0.004)\end{array}$ & $\begin{array}{c}0.070^{\wedge} \\
(0.000)\end{array}$ & $\begin{array}{c}0.086 * * \\
(0.035)\end{array}$ & $\begin{array}{c}0.047 \wedge \\
(0.008)\end{array}$ \\
\hline Log(NPCF/GDP) & & & & $\begin{array}{l}-0.004 \wedge \\
(0.000)\end{array}$ & $\begin{array}{c}-0.001 \\
(0.007)\end{array}$ & $\begin{array}{c}-0.002 \\
(0.002)\end{array}$ \\
\hline TI Corruption Index & & & & & $\begin{array}{l}-0.020^{*} \\
(0.011)\end{array}$ & \\
\hline UNHDI & & & & & $\begin{array}{c}-0.455 \\
(0.657)\end{array}$ & \\
\hline Burqual & & & & & & $\begin{array}{c}0.006 \\
(0.006)\end{array}$ \\
\hline Corruption & & & & & & $\begin{array}{c}-0.002 \\
(0.004)\end{array}$ \\
\hline Ethnic tensions & & & & & & $\begin{array}{c}-0.016 \wedge \\
(0.006)\end{array}$ \\
\hline Law\&order & & & & & & $\begin{array}{l}0.040 \wedge \\
(0.004)\end{array}$ \\
\hline Dem accountability & & & & & & $\begin{array}{c}0.004 \\
(0.005)\end{array}$ \\
\hline Government stability & & & & & & $\begin{array}{l}0.012^{\wedge} \\
(0.001)\end{array}$ \\
\hline Socioecon conditions & & & & & & $\begin{array}{l}0.018 \wedge \\
(0.002)\end{array}$ \\
\hline Investment profile & & & & & & $\begin{array}{c}0.005 * * \\
(0.002)\end{array}$ \\
\hline Pol risk & & & & & & $\begin{array}{c}-0.007 \wedge \\
(0.001)\end{array}$ \\
\hline Observations & 2946 & 2946 & 2860 & 1790 & 217 & 1017 \\
\hline Number of ID & 155 & 155 & 152 & 121 & 65 & 89 \\
\hline Wald & 0.000 & 0.000 & 0.000 & 0.000 & 0.004 & 0.000 \\
\hline Sargan & 0.083 & 0.251 & 0.4290 & 0.701 & 0.634 & 0.450 \\
\hline $\operatorname{AR}(1)$ & 0.000 & 0.000 & 0.000 & 0.000 & 0.005 & 0.000 \\
\hline $\operatorname{AR}(2)$ & 0.671 & 0.790 & 0.819 & 0.992 & 0.544 & 0.538 \\
\hline Long-run remittances coeff. & $\begin{array}{l}-0.006 \\
(0.012)\end{array}$ & $\begin{array}{l}0.003^{*} \\
(0.002)\end{array}$ & $\begin{array}{c}0.002 \\
(0.002)\end{array}$ & $\begin{array}{c}0.001 * * \\
(0.000)\end{array}$ & $\begin{array}{c}0.022 * * \\
(0.011)\end{array}$ & $\begin{array}{l}0.013^{\wedge} \\
(0.002)\end{array}$ \\
\hline
\end{tabular}

Standard errors in parentheses

* significant at $10 \%$; $* *$ significant at $5 \%$; ^ significant at $1 \%$

Notes: specifications (1) to (7) were obtained using the 2-step Anderson-Hsiao estimator (AH) and the $\mathrm{AH}$ estimator with instruments for the remittances variable. Specifications (8) to (10) were obtained using the 2-steps GMM estimator of Arellano and Bond (1991) with robust standard errors. 
Table 5 continued.

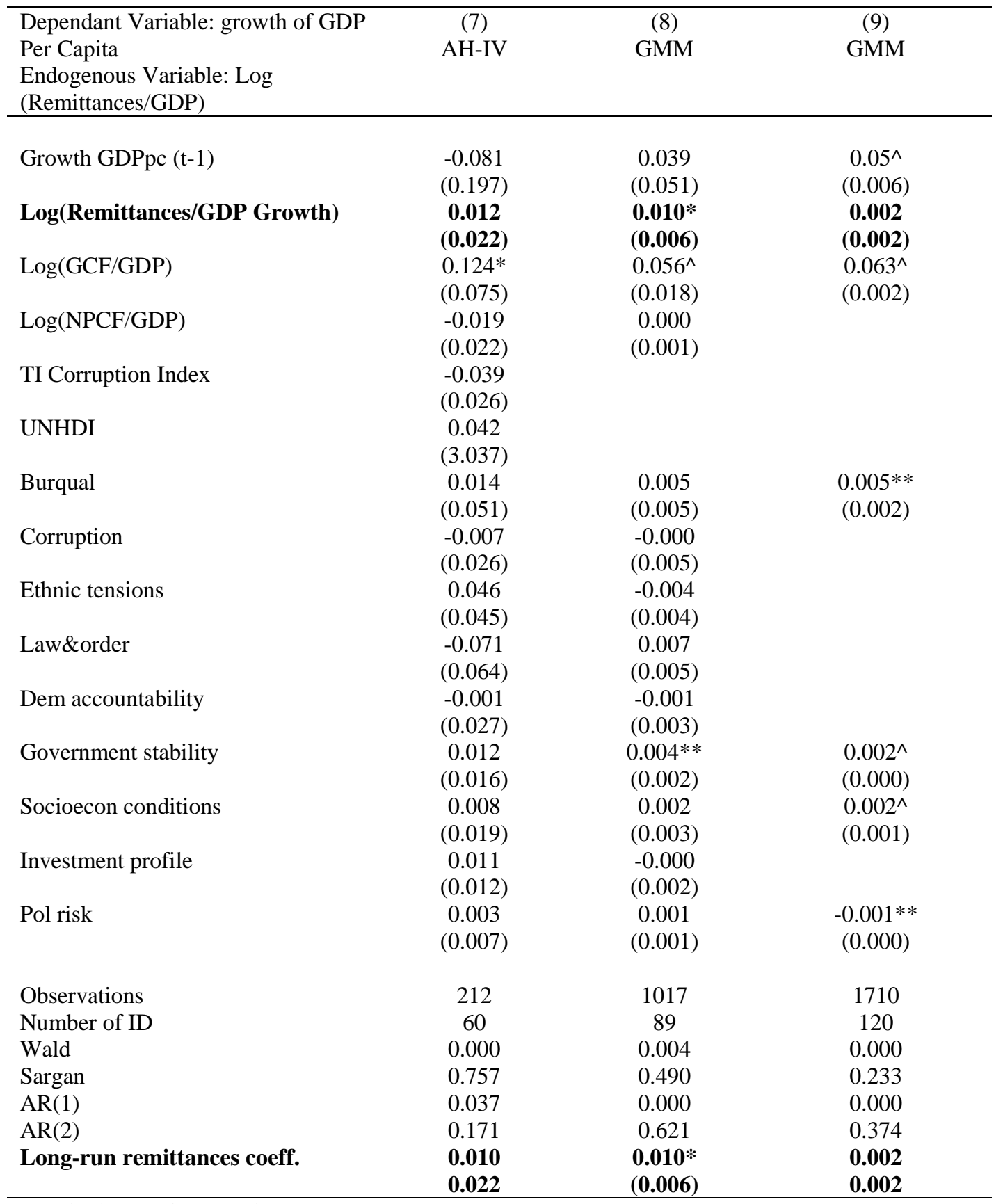

Standard errors in parentheses

* significant at $10 \%$; ** significant at $5 \%$; ^ significant at $1 \%$

Notes: specifications (1) to (7) were obtained using the 2-step Anderson-Hsiao estimator (AH) and the AH estimator with instruments for the remittances variable. Specifications (8) to (10) were obtained using the 2-steps GMM estimator of Arellano and Bond (1991) with robust standard errors. 


\section{APPENDix 2: DATA Definitions}

Workers' remittances and compensation of employees, received (US\$): Current transfers by migrant workers and wages and salaries earned by nonresident workers. This new WDI category comprising both workers' remittances and compensation of employees was introduced in mid-2005. Data are in current U.S. dollars. Source: Workers' remittances and compensation of employees, received (US\$): World Bank Development Indicators.

GDP per capita (constant 2000 US\$): GDP per capita is gross domestic product divided by midyear population. GDP is the sum of gross value added by all resident producers in the economy plus any product taxes and minus any subsidies not included in the value of the products. It is calculated without making deductions for depreciation of fabricated assets or for depletion and degradation of natural resources. Data are in constant U.S. dollars. Source: GDP per capita (constant 2000 US\$): World Bank national accounts data, and OECD National Accounts data files.

GDP (current US\$): Definition: GDP at purchaser's prices is the sum of gross value added by all resident producers in the economy plus any product taxes and minus any subsidies not included in the value of the products. It is calculated without making deductions for depreciation of fabricated assets or for depletion and degradation of natural resources. Data are in current U.S. dollars. Dollar figures for GDP are converted from domestic currencies using single year official exchange rates. For a few countries where the official exchange rate does not reflect the rate effectively applied to actual foreign exchange transactions, an alternative conversion factor is used. Source: World Bank national accounts data, and OECD National Accounts data files.

Gross capital formation (current US\$): Definition: Gross capital formation (formerly gross domestic investment) consists of outlays on additions to the fixed assets of the economy plus net changes in the level of inventories. Fixed assets include land improvements (fences, ditches, drains, and so on); plant, machinery, and equipment purchases; and the construction of roads, railways, and the like, including schools, offices, hospitals, private residential dwellings, and commercial and industrial buildings. Inventories are stocks of goods held by firms to meet temporary or unexpected fluctuations in production or sales, and "work in progress." According to the 1993 SNA, net acquisitions of valuables are also considered capital formation. Data are in current U.S. dollars. Source: World Bank national accounts data, and OECD National Accounts data files.

Private capital flows, net total (DRS, current US\$): Definition: Net private capital flows consist of private debt and nondebt flows. Private debt flows include commercial bank lending, bonds, and other private credits; nondebt private flows are foreign direct investment and portfolio equity investment. Data are in current U.S. dollars. Source: World Bank, Global Development Finance. 
Transparency International (TI) Corruption Perception Index (CPI): The TI Corruption Perceptions Index (CPI) ranks countries in terms of the degree to which corruption is perceived to exist among public officials and politicians. It is a composite index, drawing on corruption-related data in expert surveys carried out by a variety of reputable institutions. It reflects the views of business people and analysts from around the world, including experts who are locals in the countries evaluated.

http://www.icgg.org/

Human Development Index: Data are linearly interpolated by the Human Development Report Office. Otherwise data conform to those used in Human Development Report 2004. Unofficial data - received as correspondence.

\section{Governance Indicators:}

http://info.worldbank.org/governance/kkz2002/tables.asp

This page presents the updated aggregate governance research indicators for almost 200 countries for 1996-2002, for six dimensions of governance:

- Voice and Accountability

- Political Stability and Absence of Violence

- Government Effectiveness

- Regulatory Quality

- Rule of Law

- Control of Corruption

The data and methodology used to construct the indicators are described in "Governance Matters III: Governance Indicators for 1996-2002" (World Bank Policy Research Working Paper 3106).

ICRG Political Risk Rating: A means of assessing the political stability of a country on a comparable basis with other countries by assessing risk points for each of the component factors of government stability, socioeconomic conditions, investment profile, internal conflict, external conflict, corruption, military in politics, religious tensions, law and order, ethnic tensions, democratic accountability, and bureaucracy quality. Risk ratings range from a high of 100 (least risk) to a low of 0 (highest risk), though lowest de facto ratings generally range in the 30s and 40s. Monthly data were collected from www.countrydata.com, and yearly averages calculated by the authors. 


\section{APPENDIX 2: REFERENCES:}

Acemoglu, D., S. Johnson, and J. A. Robinson. (2001), "The Colonial Origins of Comparative Development: An Empirical Investigation”, American Economic Review 91: 1369-1401.

Adams, Jr., Richard H. and John Page (2003), “International Migration, Remittances, and Poverty in Developing Countries”, World Bank Policy Research Working Paper 3179

Aron, Janine (2000), “Growth and Institutions: A Review of the Evidence”, The World Bank Research Observer, 15(1): 99-135

Banaian, King and Bryan W. Roberts (2004), "Remittances in Armenia: Size, Impacts, and Measures to Enhance Their Contribution to Development”, (mimeo)

Barro, Robert J. (1991), "Economic Growth in a Cross Section of Countries”, The Quarterly Journal of Economics, 106(2): 407-443

Borjas, George J. (1999), “Economic Research on the Determinants of Immigration”, World Bank Technical Paper No. 438, Europe and Central Asia Poverty Reduction and Economic Alignment Series, September

Borjas, George J. (1999), “The Economic Analysis of Immigration”, in Handbook of Labor Economics, Volume 3A, edited by Orley Ashenfelter and David Card, NorthHolland, pp. 1697-1760

Chami, Ralph, Connel Fullenkamp, and Samir Jahjah’s (2003), “Are Immigrant Remittance Flows a Source of Capital for Development?”, IMF Working Paper WP/03/189.

De Luna Martínez, José (2005) Workers’ Remittances to Developing Countrie: A Surveu with Central Banks on Selected Public Policy Issues, World Bank Policy Research Working Paper No. 3638.

Durrand, Jorge, Emilio A. Parrado and Douglas S. Massey (1996), "Migradollars and Development: A Reconsideration of the Mexican Case”, International Migration Review 30(2)

Durand, Jorge and Douglas S. Massey (2002), "Beyond Smoke and Mirrors: Mexican Immigration in an Era of Economic Integration”, New York: Russel Sage Foundation.

Drinkwater, Stephen, Paul Levine, and Emanuela Lotti (2002), “The Economic Impact of Migration: A Survey”, paper prepared for the second Workshop of the Fifth Framework Programme Project "European Enlargement: The Impact of East-West Migration on Growth and Employment”, Vienna, December, 2002 
Easterly, W., and R. Levine (2003), “Tropics, Germs, and Crops: How Endowments Influence Economic Development”, Journal of Monetary Economics 50: 3-40.

Faini, Riccardo (2002), “Migration, Remittances, and Growth”, http://www.wider.unu.edu/conference/conference-2002-3/conference\%20papers/faini.pdf retrieved April 1, 2005

Glytsos, Nicholas P. (2002), "The Role of Migrant Remittances in Development: Evidence from Mediterranean Countries.” International Migration, Vol. 40 No 1.

Giuliano, Paola and Marta Ruiz-Arranz (2005), "Remittances, Financial Development, and Growth”, IMF Working Paper No. 05/234

Grigorian, David and Albert Martinez (2000), "Industrial Growth and Quality of Institutions: What Do (Transition) Economies Have to Gain From the Rule of Law", World Bank Policy Research Working Paper No. WPS 2475

Holzman, Robert and Rainer Munz (2004), “Challenges and Opportunities of International Migration for the EU, Its Member States, Neighboring Countries and Regions: A Policy Note”, World Bank Social Protection Discussion Paper Series No. 0411

Kapur, Devesh (2004), “Remittances: The New Development Mantra?” G-24 Discussion Paper Series, http://www.wcfia.harvard.edu/rsrchpapsum.asp?ID=795, retrieved February 21, 2005

Kaufmann, Daniel, Aart Kraay, and Massimo Mastruzzi (2003) "Governance Matters III: Governance Indicators for 1996-2002”, World Bank Policy Research Working Paper 3106, http://www.worldbank.org/wbi/governance/pdf/govmatters3_wber.pdf, retrieved April 3, 2005

Knack, Stephen, and Philip Keefer (1995), "Institutions and Economic Performance: Cross-Country Tests Using Alternative Institutional Measures.” Economics and Politics 7(3):207-227

Knack, Stephen, and Philip Keefer (1997), “Does Social Capital Have an Economic Payoff? A Cross-Country Investigation.” Quarterly Journal of Economics 112(4):12511288.

León-Ledesma, Miguel and Matloob Piracha (2004), "International Migration and the Role of Remittances in Eastern Europe”, International Migration, 42(4): 65-84.

Lucas, R.E.B. 2005, International Migration and Economic Development, Stockholm: Expert Group on Development Issues, Swedish Ministry for Foreign Affairs. 
Lucas, Robert and Oded Stark (1985) "Motivations to remit: evidence from Botswana," Journal of Political Economy, 93( 5): 901-917

Lundborg, Per and Paul Segerstrom (2002), “The Growth and Welfare Effects of International Mass Migration”, Journal of International Economics, 56(1)

Mauro, Paolo (1995), “Corruption and Growth”, The Quarterly Journal of Economics, 110(3): 681-712

Moers, Luc (1999), "Growth Empirics with Institutional Measures and its Application to Transition Economies: A Survey”, http://www.tinbergen.nl/discussionpapers/98126.pdf, retrieved April 2, 2005

Moldovan Microfinance Alliance Report (2003) “Abroad Work, Remittances, and their Utilization Patterns” (mimeo)

Orozco, Manuel. "Worker remittances, transnationalism and development,” presented in the international conference: Migrant Remittances: Development Impact, Opportunities for the financial sector and future prospects. Londres, 9 y 10 de octubre, 2003 (h).

Ratha, Dilip (2003) “Workers’ Remittances: An Important and Stable Source of External Development Finance,” Global Development Finance, World Bank, Washington, DC.

Rodrik, Dani (2004) “Getting Institutions Right”, http://ksghome.harvard.edu/ drodrik/ifo-institutions\%20article\%20_April\%202004_.pdf, retrieved March 29, 2005

Rodrik, Dani, Arvind Subramanian, and Francesco Trebbi (2002), "Institutions Rule: The Primacy of Institutions over Geography and Integration in Economic Development," http://ksghome.harvard.edu/ drodrik/institutionsrule,\%205.0.pdf, retrieved March 29, 2005

Rodrik, Dani (2001), “Comments at the Conference on 'Immigration Policy and the Welfare State'”, Trieste, June 23, 2001, http://ksghome.harvard.edu/ drodrik/papers.html, retrieved March 29, 2003

Sorensen, Ninna Nyberg (2004), “The Development Dimension of Migrant Transfers”, DIIS Working Paper No. 2004/16

Stark, Oded (2002), "Rethinking the Brain Drain”, http://econ.ucalgary.ca/research/a16RethinkingTheBrainDrain.pdf, retrieved February 28, 2005

Taylor, Edward J. (1999), “The New Economics of Labor Migration and the Role of Remittances in the Migration Process”, International Migration, 37 (1): 33-88 
World Bank (2005), Labor Study, Chapter 7: Migration in Europe and Central Asia (forthcoming study).

World Bank (2006) Global Economic Prospects: Economic Implications of Remittances and Migration, Washington, DC.

World Bank (forthcoming) Enhancing Gains from International Migraton in Eastern Europe and the Former Soviet Union, Washington, DC. 